\title{
Advancing the sustainable development goals: evidence from leading European banks
}

Article

Accepted Version

Avrampou, A., Skouludis, A., Iliopoulos, G. and Khan, N. (2019) Advancing the sustainable development goals: evidence from leading European banks. Sustainable Development, 27 (4). pp. 743-757. ISSN 1099-1719 doi: https://doi.org/10.1002/sd.1938 Available at https://centaur.reading.ac.uk/82597/

It is advisable to refer to the publisher's version if you intend to cite from the work. See Guidance on citing.

To link to this article DOI: http://dx.doi.org/10.1002/sd.1938

Publisher: Wiley

All outputs in CentAUR are protected by Intellectual Property Rights law, including copyright law. Copyright and IPR is retained by the creators or other copyright holders. Terms and conditions for use of this material are defined in the End User Agreement.

www.reading.ac.uk/centaur 
Central Archive at the University of Reading

Reading's research outputs online 


\title{
Advancing the Sustainable Development Goals: Evidence from leading European banks
}

\begin{abstract}
The Sustainable Development Goals (SDGs) reflect grand challenges the global community needs to address in order to ensure economic welfare, environmental quality as well as social cohesion and prosperity for future generations. In this respect, the role of the banking sector, among other critical business entities and key stakeholders, is vital. The purpose of our paper is to examine how comprehensively the reported performance of banks aligns with the endorsement of the SDGs. We employ the well-established framework of the Global Reporting Initiative (GRI) performance indicators for a comparative assessment of the nonfinancial performance disclosed in the annual sustainability reports. Focusing on a small sample of leading European banks, we find an overall low contribution to the SDGs. Furthermore, each bank's contribution remains particularly heterogeneous towards most individual SDG goals. Likewise, bank-specific strategies drive the most extensively addressed SDGs, overlooking any critical importance of certain GRI indicators with multifaceted impact across several SDGs. The study sets forth managerial implications for improving effective reporting of SDG performance. It concludes with emerging opportunities for enhancing disclosure of SDGs contribution and highlights future research perspectives towards industry-wide shared-value appraisal under the scope of these pressing grand challenges.
\end{abstract}

Keywords: Sustainable Development Goals (SDGs), banking sector, Global Reporting Initiative (GRI) guidelines, sustainability accounting and reporting. 


\section{Introduction}

The 2030 agenda for sustainable development was adopted by the United Nations' member states as 17 SDGs at the New York summit in September 2015 (Howard-Grenville et al., 2017; Nilsson et al., 2016), ahead of the Paris Agreement on Climate Change that followed in December of the same year (Schurer et al., 2018). The SDGs set the overarching global trajectory towards a more sustainable future. As the former UN Secretary-General, Ban Ki-moon, aptly summarized "we are the first generation that can end poverty, and the last one that can take steps to avoid the worst impacts of climate change" (UN, 2015a). The United Nations (UN) high-level working groups have since been developing governance policies and reporting frameworks (Dsouli et al., 2018; Hajer et al., 2015) aiming to engage the diverse stakeholder groups towards identified goals, e.g. by reshaping governmental and ministerial roles, adjusting industry standards and regulations, setting broader accounting and reporting mechanisms of transnational organizations, changing daily habits of local civil societies, endorsing the sustainability-specific transformation of private sector technologies as well as scientific innovations (Stafford-Smith, et al., 2017). According to the UN Global Compact (2017), the international business community is rapidly embracing SDGs, more commonly referred to as "Global Goals" that consist an emerging 'doxa' (see Storey et al. 2017) to which the banking sector in particular is deemed to be of vital importance, as their implementation requires significant amounts of capital flows, investments and redistribution of funds (Raut et al., 2017; Jeucken and Bourma, 2017; Weber, 2005; Koellner et al., 2005). It is critical that the multi-level networks in each industry to promote further collaborative working and cross-dissemination of research findings, reporting outcomes, best practices and impactful contributions towards achieving these overarching goals (Bebbington and Unerman, 2018; Annan-Diab and Molinari, 2017; Schaltegger et al., 2017; Xiao et al., 2017).

Numerous business entities, including banks, are nowadays placing emphasis on their corporate sustainability agenda (Kolk et al., 2018; Carroll and Shabana, 2010; Dahlsrud, 2008; Matten and Moon, 2008; Van Marrewijk, 2003), as a set of relatively self-regulated contribution to the SDGs which is being reported through various communications and stakeholder engagement channels, e.g. the corporate website, social media channels, press releases, sustainability or other dedicated reports (e.g Citigroup) as well as league tables on SDGs' implementation status. According to PricewaterhouseCooper (PwC, 2017), 62\% of companies mention SDGs in their disclosures while $79 \%$ of companies give priority to aspects pertaining to SDG13 (Climate Action). However, it is only $28 \%$ of companies that set quantitative targets linked to their relative impacts, in the form of at least one Key Performance Indicator (KPI) (PwC, 2017). Similarly, among the companies subscribed to the Global Compact, $72 \%$ claim to be taking actions towards the SDGs (UN Global Compact, 2017). Focusing on the banking industry, despite the increasing emphasis on strategically focused and technologically advanced innovations, research on sustainability perspectives leaves much to be desired. The challenge of how banks' sustainability performance can be more comprehensively assessed to allow comparative analyses between different organizations, across regions over time periods remains a pressing issue. 
Our study proposes a structured framework for comparative assessment of overall organizational operation in terms of contribution to the SDGs. In this regard, the sustainability reports published according to the GRI guidelines - the most widely-accepted nonfinancial reporting framework - are utilized. The following analysis relies on the correspondence of the 17 SDGs to specific subsets of the GRI performance indicators, already identified by the SDG Compass (https://sdgcompass.org/), an initiative developed by the GRI, the UN Global Compact and the World Business Council for Sustainable Development (GRI, 2015). The proposed assessment method is applied to a small sample of European banks, which are considered leaders in sustainability management, according to their listing in the Dow Jones Sustainability Index. Raut et al., (2017) indicates that European banks are indeed concerned on certain environmental, social and governance aspects of performance. This corroborates with their relative number of signatories to the Equator Principles ${ }^{1}$ and support to the United Nations Environment Programme - Finance Initiative $(\mathrm{UNEP}-\mathrm{FI})^{2}$ statements. The European banking system contributes most to financial mediations and the EU's GDP, compared to other advanced economies (Raut et al., 2017).

The rest of the paper is structured as follows. Section 2 binds the literature reviews on the SDGs and emerging sustainability reporting practices in the banking sector. Section 3 outlines our sample, the proposed assessment method and the data gathering approach. The findings are presented and discussed in section 4. The paper concludes and indicates limitations as well as implications of our study in the final section.

\section{Background}

\subsection{The Sustainable Development Goals (SDGs)}

The United Nations was established in post world-war 1940s and replaced the League of Nations (Zimmern, 1936). It was tasked with building global cooperation as well as conflict or crisis prevention (MacQueen, 2018; De Coning, 2018) and has grown from 51 member states (1945) to 193 member states (2018). In recent years, a 'hot dialogue' is taking place regarding sustainable development through economic, social and environmental considerations (Brohe, 2018) within the forums of the United Nations Development Programme (UNDP); the United Nations Environment Programme (UNEP); the World Health Organization (WHO); the United Nations Children's Fund (UNICEF); the United Nations Educational, Scientific and Cultural Organization (UNESCO); and other international development agencies attending the Millennium Development Goals (MDGs) (Kumar et al., 2016). The 2030 agenda for sustainable development came into force in January 2016, translating into 17 SDGs and 169 targets (UN, 2015b), categorized into three major clusters: cluster one consists of SDGs 1-7 including the extension of the MDGs for 2030, cluster two focuses on social inclusiveness (SDGs 8-10) and cluster three (SDGs 1117) pertains to urban sustainability (Kumar et al., 2016). Policy-makers that adopted the 2030

\footnotetext{
${ }^{1}$ http://equator-principles.com/; 94 financial institutions from 37 countries.

2 http://www.unepfi.org/banking/bankingprinciples/; Principles for Responsible Banking, supported by 28 banks.
} 
Agenda for Sustainable Development made a "...call on all businesses to apply their creativity and innovation to solving sustainable development challenges" (UN,2015b. p.29) as there is a strong consensus that the SDGs can only be achieved with the active involvement of the private sector working alongside governments, the UN system and other international institutions, local authorities, civil society members, the scientific and academic community - and society at large.

The Financial Services industry, including banks, is a key enabler for the real economy. In this respect, the transition to a sustainable and inclusive global economy by 2030 requires vast amounts of capital, estimated at \$5-7 trillion each year (UN, 2014). Most of these funds are to drawn from the private sector and financial institutions therefore have a central role to play by redirecting funds to promote sustainable growth and by improving access to financial services so no one becomes laggard in this transition. According to the UN Global Compact and the KPMG International, financial services support improves economic well-being which consequently increases the ability of households and the public sector to improve social outcomes (UN Global Compact and KPMG International, 2015). The biggest opportunities for shared-value creation are grouped around the following themes: access to capital (financial inclusion), investments in renewable energy and other infrastructure projects, risk assessment (leveraging risk expertise to directly influence customer behavior and to create more resilient nations) and cross-cutting perspectives (positively influencing environmental, social and governance practices of corporate clients and investee companies). Moreover, according to the same report, SDGs provide a unique opportunity for companies to create added-value through developing, for example, products and services for consumers of low income, improving employees' well-being, as well as that of their contractors along with their suppliers' productivity output (UN Global Compact and KPMG International, 2015).

\subsection{Corporate sustainability reporting and the banking sector}

According to the World Business Council for Sustainable Development, corporate sustainability reporting indicates "public reports (published) by companies (in order) to provide internal and external stakeholders with a picture of corporate position and activities on economic, environmental and social dimensions (...) in short, such reports attempt to describe the company's contribution toward sustainable development." (WBCSD, 2002, p. 7).

There are several alternative approaches in devising sustainability report contents (Fijałkowska et al., 2018; Yongvanich and Guthrie, 2006; Schaltegger and Wagner, 2006) such as the Triple Bottom Line (TBL) approach, the Intellectual Capital (IC) framework or the Balanced Scorecard (BSC). Yet, the Global Reporting Initiative (GRI) set of guidelines is internationally accepted and constitutes the most widely-acknowledged framework for sustainability/nonfinancial reporting. The first version of the GRI Guidelines was launched in 2000, representing the first global framework for comprehensive sustainability reporting. The second, third and fourth versions, were launched in 2002, 2006 and 2013 respectively. The fourth version of the GRI guidelines (GRI-G4) has been replaced in mid-2018 by the GRI 
Standards (www.globalreporting.org/standards/) which is the most recent version of the GRI framework. The GRI guidelines framework is fundamentally based on the application of the triple bottom line perspective of organizational performance - economic, social, and environmental - and its implementation allows tracking performance over time and between different companies as it promotes the application of a common set of comparable and verifiable indicators. It should be noted that the external/third-party assurance of sustainability disclosures is of critical importance in the GRI framework as it has a direct effect on the credibility and integrity of the overall nonfinancial accountability process.

Prior research suggests that banks adopting sustainability principles tend to have significantly better performance on asset and equity returns (Shen et al., 2014), as well as increased revenue while there is negative correlation with nonperforming loans (Wu and Shen, 2013). In a similar vein, Forcadell and Aracil (2017) suggest that strengthening the reputation of banks through the incorporation of sustainability-related practices in everyday operations eventually improves their overall performance. Nevertheless, Weber et al. (2014) indicate that the sector's performance is relatively low in sustainability terms. Weaknesses of the financial sector in terms of sustainability management have been pinpointed to be its external reporting-accountability practices, aspects pertaining to business ethics and product responsibility as well as labor issues. In contrast, relative strengths regarding sustainability endorsement can be identified in the community relations domain (Venturelli and Cosma, 2018, Miralles-Quiros et al., 2017; Weber et al., 2014).

Well-established approaches in evaluating the content of sustainability reports according to Evangelinos et al. (2009) can be grouped into three general categories: content analysis methods, questionnaire-based surveys and evaluation assessments through scoring schemes. The last group, where the present study contributes to, classifies sustainability information in different scales according to their quality and comprehensiveness and quantifies it based on a numerical grading scheme, allowing the ranking of reports and facilitating comparability. International organizations such the United Nations Environmental Program (UNEP) and Deloitte Touche Tohmatsu have developed guidelines to evaluate these reports (e.g. see Morhardt et al., 2002). Motivated by these approaches and given that the GRI is currently the primary mover in sustainability reporting, in this study a scoring method based on GRI performance indicators has been devised and appropriately adapted to assess SDGs' endorsement.

\subsection{Sustainability indices}

Even though there are many indices concerning ratings of corporate sustainability (e.g the FTSE4Good Index Series, the Carbon Disclosure Project Leadership Index or the MSCI ESG Indexes), the Dow Jones Sustainability Index (DJSI) is the most well-established one and considered most credible among the 16 most broad investor-oriented ratings (Sadowski et al., 2010). Supporting evidence for this claim can be found in a study conducted as a part of the Rate the Raters project where over 100 ratings were inventoried and a global group of 
sustainability experts on certain aspects of ratings and related issues where surveyed (Sadowski et al., 2010).

The DJSI was launched in September 1999 and, over time, regional indices were launched, forming the family of Dow Jones Sustainability Indices. According to the DJSI, this group of indices is the first global sustainability benchmark tracking the stock performance of the world's leading companies in terms of economic, environmental and social criteria. Created jointly by S\&P Dow Jones Indices and RobecoSAM, the DJSI combines the experience of an established index provider with the expertise of a specialist in sustainability rating and investing to select the most sustainable companies across 60 industries. The RobecoSAM Corporate Sustainability Assessment (CSA) is the annual evaluation of companies' sustainability practices classifying business entities with outstanding performance to gold, silver and bronze class.

\section{Material and methods}

Our assessment method is applied to five leading European banks (see Table 1). The first criterion for sample selection was to include organizations categorized as "Banks" in the 2017 Dow Jones Sustainability Index (DJSI). Second, the sample was limited to those receiving a distinction in RobecoSAM CSA, i.e. included as bronze, silver or gold class in 2017 for their sustainability management practices (based on performance 2016 supplied data). Third, the sample was reduced to banks registered in European countries. As no European bank is included in the gold-level classification, the sample comprised of only silver and bronze class organizations. Fourth, the sample organizations should have disclosed their sustainability performance under the GRI-G4 reporting framework. In order to facilitate comparability across the sample's reports, we did not opt for the latest version of the GRI framework (the 'GRI Standards') as most companies have yet to fully adopt this new set of guidelines in preparing their reports. Thus, one bank which has already adopted the "GRI Standards" was excluded from the sample, as was one more that did not disclose a GRI Contents Index, a navigation instrument necessary in making information traceable, increasing the value of the reported data and the overall clarity, completeness and transparency of the report.

\section{INSERT TABLE 1 HERE}

A two-stage data collection process was followed to gather the most recent nonfinancial reports of the selected banks. During the first stage, (database.globalreporting.org/) a related search in the GRI database was conducted using the bank's name and the respective reporting year. In the second stage, for certain banks whose nonfinancial report could not be traced in this database, a dedicated search on the corporate website was performed. The reporting period for all banks referred to the 2016 calendar year. 


\subsection{Linking SDG-GRI assessment}

In order to evaluate the endorsement of SDGs disclosed in the reports, a link to respective GRI performance metrics was necessary. To achieve this, the SDG Compass was utilized (GRI et al., 2015) which links each of the 17 SDGs with an individual set of business themes and to a specific set of GRI performance indicators. The GRI indicators used in our assessment pertain to both standard GRI-G4 performance metrics as well as the GRI Sector Supplement indicators for the Financial Services (FS) sector (Appendix 1).

According to this SDG Compass correspondence, each business theme may be linked to none, one or multiple GRI indicators. Business themes which are not linked to any generic or FS indicators were excluded from the assessment. Out of these 44 business themes, any lack of information found in certain ones does not reflect suboptimal reporting but rather sustainability goals not applicable to the banking industry (e.g. food labeling). For business themes corresponding to multiple GRI indicators, the business theme score was a function of the average score resulting from the GRI indicators linked to it. Likewise, for business themes corresponding to single GRI indicators, the GRI indicator score reflects the business theme score.

The compilation of certain GRI indicators requires information that is much broader than the information needed to provide an SDG's endorsement status. For those indicators, the evaluation process was adapted by placing emphasis on these performance aspects of the GRI indicator which are directly relevant to the specific SDG. Thus, there are cases of reporting entities whose GRI reporting scores may vary from the evaluation scores referring to the scope of the present SDG-focused assessment. Such cases occurred when the bank disclosed comprehensively the SDG-specific aspects of the GRI indicator but reported insufficiently aspects rather not relevant to the SDG. For instance, the SDG5 business theme "Women in Leadership" corresponds to the G4-LA12 indicator which assesses the equal participation of individuals in governance bodies in terms of gender, age group or minority status. If the reporting entity provides full and systematic reporting on gender representation in the G4LA12 indicator, the respective score would be high. In contrast, if the reporter provides full and systematic reporting on minority status representation but not on gender, the score is low and the respective business theme and SDG score are affected accordingly. To ensure consistency in the linkage between the GRI indicators, the SDG business themes and the SDGs, the online Inventory of Business Indicators of SDGs Compass (https://sdgcompass.org/business-indicators/) was also taken into consideration.

The process followed to implement the reporting assessment began with a search for the GRI Contents Index. These tables located in each sustainability report or in a separate document cite which GRI-G4 indicators are disclosed in the report, or in other reporting medium of the bank such as the annual report or the corporate website, along with their exact location (such supplementary material which we reviewed is mentioned in the last column of Table 1). In this respect, only clear and accurate references to specific information/section of the website or other document(s) were taken into consideration. For each one of these indicators, the respective sections were examined and evaluated based on the scoring system described in the next section. 


\subsection{Scoring system}

A scoring system was developed to assess the reporting standards of selected banks. In line with prior studies (e.g. Skouloudis et al., 2009; 2010; 2011; Halkos and Skouloudis, 2016), this grading scheme attempts to rate qualitative and quantitative performance information using a 5-point quantitative measurement scale for SDG performance. Scores reflect the report's capacity to provide detailed information on each of the disclosed GRI indicators, and, consequently, of the business themes pertaining to the 17 SDGs. Under this scoring system, zero points are assigned for no relevant information, 1 point is assigned for generic statements lacking clear data/information, 2 points for specific-clear, yet, limited information, 3 points for extensive relevant disclosures, and the maximum score (4 points) for full and systematic reporting of information in line with the GRI guidelines. The assessment was performed independently by three experienced researchers in relevant grading schemes. There was a small number of scoring criteria where discrepancies in the three sets of scores was identified. These were reexamined by the coders and modified accordingly to address issues pertaining to inter-coding errors and reliability issues.

Some business themes corresponded to a larger number of GRI indicators (e.g. SDG 1 or SDG 10) than others. Likewise, some SDGs include a greater number of business themes than others (e.g. SDG8 refers to 24 business themes). In this respect, the assumption that: (a) all GRI indicators contribute equally to each business theme they correspond and (b) all SDG business themes contribute equally to the SDG they correspond, was deemed to be appropriate for our analysis. Consequently, the score of each business theme is estimated as the mean score assigned to the sum of (both generic and FS-specific) GRI indicators referring to the respective business theme. Likewise, the score for every SDG is estimated as the mean score of all related business themes. No weighting criteria is applied to the business theme evaluation. The overall score is estimated as the sum of all SDG scores divided by the total number of SDGs. In this way, both the score per SDG as well as the total score per Bank had maximum score of 4 .

An overview of the number of the business themes and GRI indicators system is presented in Table 2.. A total of 68 different business themes and 71 GRI indicators are found across the 17 SDGs.

\section{INSERT TABLE 2 HERE}

\section{Findings and discussion}

The analysis of the reporting practices of the five selected banks is outlined across four dimensions: (1) aggregated disclosure on SDGs endorsement by each bank, (2) comprehensiveness of reporting per SDG 'criterion', (3) reporting across specific business themes within each SDG and (4) reporting per GRI indicator disclosed. 


\subsection{Aggregated performance across banks}

An overview of the reporting scores for the five banks is presented in Table 3 and illustrated in Figure 1.

\section{INSERT TABLE 3 AND FIGURE 1 HERE}

The overall assessment of reporting performance across banks reveals some interesting findings. First, the overall disclosure of all banks on the SDGs is considerably low. The mean disclosure score across banks is 0.78 on the $0-4$ scale. Practically, this score suggests that the selected banks fail to cover SDG reporting goals when developing their GRI-based sustainability reports. This disclosure score does vary across the five banks. The best performing bank is Intesa Sanpaolo SpA which scores higher than any other bank in 13 out of the 17 SDG criteria. Additionally, it is the only bank which consistently achieves scores close to 2 points (specific, yet, limited information) in most of the SDG criteria. It should also be noted that this bank includes the correspondence between the disclosed GRI indicators and the SDGs in the GRI Index Table. The other four banks demonstrate average reporting scores which do not exceed the value of 1 (generic statements), suggesting a lack of commitment either in providing clear information of sustainability management practices reporting or on tracking progress on SDG objectives.

An inspection of the standard deviation of average reporting scores across banks indicates that there is significant variability in SDG criterion disclosure even within the same bank, as evidenced by standard deviations presented in Table 3 which, in some cases, exceed mean reporting scores(e.g for CaixaBank SA standard deviation is 1 while the mean disclosure score is 0.69). The reporting scores are not equally distributed across criteria, and for certain reporters, the average score is a result of 'good' disclosure of one SDG criterion which drives the overall performance score up despite the poor reporting performance in all other SDGs. For instance, Caixabank receives the third higher disclosure score $(0.69 / 4)$ despite scoring lower than all the other banks in many SDGs just because it placed emphasis on a single SDG (i.e. SDG4). Although the small sample and subsequent data points do not allow for robust statistical testing, it is likely that banks' disclosure is not evenly spread out across sustainability goals but rather emphasizes on a limited set of sustainability dimensions and disregarding others.

\subsection{Reporting on each of the SDGs}

Focusing on the 17 SDGs, it becomes apparent that the overall low completeness of disclosures can to a large extent be observed across individual reporting criteria (Table 3). Out of the 17 SDGs, it is only three that exceed, on average, the score of 1 point on the $0-4$ scale. Specifically, the most 'well-reported' SDG is SDG4 ("Ensure inclusive and equitable quality education and promote lifelong learning opportunities for all") reaching a score of 2.30/4, followed by SDG8 ("Promote sustained, inclusive, sustainable economic growth, full productive employment, and decent work for all") with a 1.18/4 score and SDG16 ("Promote peaceful and inclusive societies for sustainable development, provide access to justice for all 
and build effective, accountable and inclusive institutions at all levels") with a score of 1.05/4. In contrast, the SDG criteria with the lowest scores are SDG17 ("Strengthen the means of implementation and revitalize the global partnership for sustainable development"); score:0.20/4, SDG6 ("Ensure availability and sustainable management of water and sanitation for all"); score: 0.24/4, SDG14 ("Conserve and sustainably use the oceans, seas and marine resources for sustainable development"); score: 0.35/4, and SDG15 ("Protect, restore and promote sustainable use of terrestrial ecosystem, sustainability, manage forests, combat desertification and halt reverse land degradation and halt biodiversity loss") with a score of $0.35 / 4$.

Despite the overall low evaluation scores, subtle differences in the ranking of SDG reporting suggest that there might be industry effects evident in SDG disclosures which drive the discrepancies in those scores. Financial institutions' core business does not extensively revolve around the management of environmental resources such as water, forests, land or marine infrastructure, thus rendering sustainability reporting around such areas as potentially secondary and/or redundant to assess in their sustainability reporting practices. In contrast, the key resource employed by banks is human capital whose promotion and preservation is assessed as critically important in their reported actions and disclosed practices. A PwC survey (PwC,2017) concerning corporate sustainability reports published in the same year (2016) points out that, in some cases, prioritization of SDGs is due to their alignment with existing business strategies. The study indicates as top priority SDGs for financial institutions SDG13, SDG8, SDG4 and SDG11 as well as SDG3, all of which are included in the highest rated in the results of this analysis (Table 4). Similarly, businesses subscribed to the Global Compact place comparatively more emphasis on SDGs 8, 3, 5, 4, 12, 9 and 13 with only two of those absent form those highest rated in this analysis: SDG12 ("Responsible consumption") and SDG9 ("Innovation and infrastructure") (UN Global Compact, 2017).

\section{INSERT TABLE 4 HERE}

The assessed banks have included in their reports a clear reference of their contribution to certain SDGs according to initiatives they implement. In this respect, in Table 5 we sought for an overall review of the banks' claims vis-à-vis the results of our assessment. The comparison highlighted 6 out of 85 cases where the reporting entity claimed that it contributes to a specific SDG through related initiative(s) without such claims being adequately confirmed by the analysis scores.

\section{INSERT TABLE 5 HERE}

\subsection{Reporting on SDG business themes}

Scores across business themes show significant variation in the comprehensiveness of reported information similar to the one of the SDG criteria. The highest scores (Table 6) are obtained for business themes referring to labour practices such as those of general employment (2.07/4), youth employment (3.00/4) as well as employee training and education (2.23/4). High reporting scores were also assigned for business themes related to 
inclusiveness and diversity in the workplace in terms of gender equality (2.60/4), participation of women in upper management (2.13/4) and equal opportunities to all employees (2.00/4). Finally, a set of business themes referring to ethical concerns also received above average reporting scores with particular attention to customer privacy protection (2.40/4) as well as ethical and lawful behavior (2.13/4). Across all these business themes, average reporting scores are equal to or exceed the value of 2 points suggesting an adequate, albeit not extensive, disclosure of performance information. These business themes almost exclusively fall within the generic SDG criteria where highest average scores were also achieved, suggesting correlation between business themes and general SDG criteria.

\section{INSERT TABLE 6 HERE}

In contrast, $\sim 15 \%$ of all individual business themes (13 out of 68 ) are not discussed at all in the five sustainability reports, thus receiving zero points. These business themes include, among others, water efficiency and water quality linked to SDGs 6 and 7 as well as infrastructure investments linked to SDGs 5, 7, 9 and 11. Crucially, these business themes span across 13 out of the 17 SDGs, leaving 4 SDGs for which non-zero reporting scores are obtained for all underlying business themes. This trend suggests that sample banks do not follow the SDG rationale when deciding which activities to report on but rather tend to focus on more concrete and explicitly-defined performance areas (corresponding to lower level business themes) in their reporting practices. Zero scores are also obtained in business themes within SDGs that the sample banks scored both relatively high (e.g. SDG8 business themes such as the elimination of forced and/or compulsory labor) and relatively low (e.g. SDG14 business themes such as marine biodiversity). It is worth noting, though, that some of these results can be attributed to either (a) industry specificities as is the case with generic SDG criteria (e.g. reporting on water discharge to oceans which is unrelated to financial institution operations), or (b) to sample specificities emerging from the sample composition which includes only financial institutions largely operating in countries where certain sustainabilityrelated practices (e.g. abolishment of child labor) are incorporated in the national legalregulatory framework.

Since certain business themes are included in the assessment of more than one SDG, an additional analysis was conducted to investigate whether business themes that are used multiple times in the assessment of SDG criteria tend to be given higher assessment scores. To investigate this further, a correlation analysis was conducted between the number of times a business theme score is used to assess an SDG business theme and the average reporting score obtained for the corresponding SDG criterion ( $\mathrm{n}_{\text {busness_themes }}=68$ ). Surprisingly, the results of the Pearson's correlation coefficient, $r$, suggest that indicators that are used to assess more than one SDG business themes tend to be assessed with lower average SDG reporting scores $(\mathrm{r}=-0,259, \mathrm{p}=0.033<0.05)$, at the $5 \%$ level of statistical significance. This implies that when reporting sustainable practices, the sample's banks may ignore the critical importance of business themes which have multifaceted impacts/contribution to the disclosure needed across several SDGs. For example, although not included in the top 10 business themes scores, "Environmental investments" is related to SDGs 7, 9, 12, 13, 14, 15 and 17, "Infrastructure investments" is related to SDGs 2, 5, 7, 9 and 11, "Access to financial 
services" is related to SDGs 1, 8, 9 and 11, "Energy efficiency" is related to SDGs 7, 8, 12 and 13, while business theme "Equal remuneration for women and men" is refers to SDGs 5, 8 and 10.

\subsection{Disclosure of GRI performance indicators}

Scores across GRI indicators reveal significant variation in comprehensiveness, similar to those of the SDGs and business theme scores. The highest scores (Table 7) are obtained for GRI indicators linked to general, standard, disclosures of the GRI guidelines (e.g. issues concerning labour practices, organizational value systems and codes of conduct) and not to performance indicators (e.g. environmental or human rights performance).

\section{INSERT TABLE 7 HERE}

Similar to the business themes findings, some GRI indicators are used for the assessment of more than one SDG business theme. Following a correlation analysis between the number of times a GRI indicator score is used to assess an SDG business theme and the average reporting score obtained for the corresponding SDG criterion (n in terms of the Pearson's correlation coefficient suggest that those indicators that are used to assess more than one business themes tend to be assessed with lower average SDG reporting scores $(\mathrm{r}=-0.258 ; \mathrm{p}=0.03<0.05)$, implying that indicators with disclosure impact across multiple SDGs are not prioritized-emphasized. Such GRI indicators are G4-EN31 ("Total environmental protection expenditures and investments by type") relevant for SDGs 7, 9, 12, 13, 14, 15 and 17, G4-EC8 ("Significant indirect economic impacts, including the extent of impacts") which is relevant to SDGs 1, 2, 3, 8, 10 and 17, as well as G4-EN27 ("Extent of impact mitigation of environmental impacts of products and services") linked to SDGs 6, 8, 12, 13, 14 and 15 (see Appendix 2). This indicates that there is significant room for improvements in sustainability (i.e. SDG-specific) reporting by placing emphasis on certain GRI metrics when these tend to be relevant to multiple SDG business themes.

Moreover, although 19 out of most-frequently disclosed GRI indicators (according to the methodology applied - see Appendix 2) are environmental performance indicators, such as G4-EN31 ("Total Environmental Protection Expenditures and investments by type"), it is only one that was included in the top 10 score-related GRI indicators, i.e. G4-EN16 ("Indirect greenhouse gas emissions - Scope 2"). This may be attributed to the sample banks' participation to the Carbon Disclosure Project (CDP) corroborating the assumption that companies prioritize SDGs according to existing reporting commitments to third-party business standards they support such as the CDP (PwC, 2017).

\section{Concluding remarks}

This study provides a comparative assessment method concerning the banking sector's reported contribution to the SDGs relying on information disclosed in corporate sustainability 
reports. Following relevant modifications it can be applied to different business sectors as well. The proposed approach follows a scoring system approach for rating disclosures in nonfinancial reports which does not evaluate companies' performance per se but rather the completeness/comprehensiveness of the performance-related information included in the report (Skouloudis et al, 2009). Consequently, it assesses the banks' disclosed claims and supporting evidence on their contribution to SDGs rather than their actual performance.

The results highlight a rather limited overall reporting performance on organizational contribution to the SDGs with heterogeneous disclosure levels per different SDG for all sample banks. Moreover, it can be assumed that banks of the sample do not follow an 'SDG rationale' when opting for which activities to report on. The aforementioned claim may be attributed to the fact that the evaluated reports are referring the reporting period of 2016, which was actually the first year that the SDGs came into force.

From a managerial standpoint, although the proposed method evaluates the disclosed information concerning SDGs, it can be employed as a potential internal audit instrument and perhaps a prerequisite for better performance monitoring and accountability on such aspects. Moreover, focusing on GRI indicators (as well as business themes) which are relevant to multiple SDGs can potentially improve disclosure contents and overall comprehensiveness under the scope of SDG reporting. Such business themes and indicators are "Environmental investments", "Infrastructure investments", "Access to financial services", "Energy efficiency", "Equal remuneration for women and men" and G4-EN31, G4-EC8, G4-EN27 respectively. In this respect, and in order to prioritize policy for more effective contribution to the SDG framework and the reported progress over achieving these global indicators, it should also be taken into consideration that they can be largely complementary and in some cases dependent upon one another (Singh et al., 2017). Likewise, the analysis highlights that banks should establish a flexible primary and secondary targets-setting process (Figure 1), that is evidence-led and allows for transparent annual reporting aligned with the 17 SDGs.

The results of such study primarily depend on the level of completeness of the reported performance according to the GRI guidelines. In this respect, this assessment has applied a novel method to a small sample of leading banks which were selected from the 2017 DJSI listing. Thus, longitudinal studies, drawing from larger samples which may rely on sustainability indices other than the DJSI may yield very different results. Moreover, the study focuses exclusively on the financial sector and thus the generalizability of the findings in other industries cannot be assumed. Nevertheless, the observed patterns in sustainability reporting can form interesting insights for trends in reporting behavior of firms in other industries and contexts in light of the increasing relevance and mainstreaming of the SDG framework.

Beyond the above limitations, future research could examine the implementation of the proposed assessment method according to the recently launched GRI Standards (GRI, 2017) including an SDG targets analysis. Monitoring the organizational disclosure over time in relation to the pertinent EU adaptation of the 2030 Agenda for Sustainable Development (European Union, 2017) is also a fruitful avenue to investigate. This is considered to be of 
particular importance, following the introduction by UNEP-FI and 28 banks of the Principles for Responsible Banking for global public consultation on $26^{\text {th }}$ November 2018. The Principles are to be launched in September 2019 and aim to refine a bank's contribution to achieving societal goals as expressed in the SDGs and the Paris Climate Agreement. (UNEP, 2018). Thus, relevant studies including both larger samples as well as banks from other regions would certainly provide some fruitful as well as actionable insights. 


\section{References}

Annan-Diab F, Molinari C. 2017. Interdisciplinarity: Practical approach to advancing education for sustainability and for the Sustainable Development Goals. The International Journal of Management Education 15(2): 73-83. DOI: 10.1016/j.ijme.2017.03.006

Ballate A. 2018. Shaping our World for a Better Tomorrow: Sustainable Investing, ESG, and Industry Insight. Independent Study Project (ISP) Collection. 2805. https://digitalcollections.sit.edu/isp_collection/2805

Bebbington J, Unerman J. 2018. Achieving the United Nations Sustainable Development Goals: an enabling role for accounting research. Accounting, Auditing \& Accountability Journal 31(1): 2-24. DOI: 10.1108/AAAJ-05-2017-2929

Bondy K, Starkey K. 2012. The dilemmas of internationalization: corporate social responsibility in the multinational corporation. British Journal of Management 25(1): 422. DOI: $10.1111 /$ j.1467-8551.2012.00840.x

Brohe A. 2018. Driving standardization of ESG reporting: WFE Guidelines and Metrics mapped to GRI standards. Article published $17^{\text {th }}$ October 2018 by Global Sourcing Council. Available at: https://www.gscouncil.org/driving-standardization-of-esgreporting-wfe-guidance-and-metrics-mapped-to-the-gri-standards/ [Accessed $25^{\text {th }}$ Oct. 2018].

Carroll A, Shabana K. 2010. The business case for corporate social responsibility: A review of concepts, research and practice. International journal of management reviews 12(1): 85-105. DOI: 10.1111/j.1468-2370.2009.00275.x

Citigroup Inc. 2017. Banking on 2030: Citi \& the Sustainable Development Goals [online] Available at: http://www.citigroup.com/citi/about/citizenship/download/Banking-on2030-Citi-and-the-SDGs-Report.pdf?ieNocache $=68$ [Accessed $30^{\text {th }}$ Apr. 2018].

Dahlsrud A. 2008. How corporate social responsibility is defined: an analysis of 37 definitions. Corporate social responsibility and environmental management 15(1): 1-13. DOI: $10.1111 / \mathrm{j} .1467-8551.2012 .00840 . x$

De Coning C. 2018. Sustaining peace. Can a new approach change the U.N? Global governance spotlight. Published by development and peace foundation. Available at: https://brage.bibsys.no/xmlui/bitstream/handle/11250/2496844/GGS_201803_Coning_en_2018-04-16_MR.pdf?sequence=1 [Accessed 15 ${ }^{\text {th }}$ Dec. 2018]. 
Dsouli O, Khan N, Kakabadse N, Skouloudis A. 2018. Mitigating the Davos dilemma: towards a global self-sustainability index. International Journal of Sustainable Development \& World Ecology 25(1): 81-98. DOI: 10.1080/13504509.2016.1278565

European Union. 2017. A sustainable European future: The EU response to the 2030 Agenda for Sustainable Development. [online] Available at: http://www.consilium.europa.eu/en/ press/press-releases/2017/06/20/agenda-sustainable-development/ [Accessed 30 ${ }^{\text {th }}$ Apr. 2018].

Evangelinos K, Skouloudis A, Nikolaou I, Filho WL. 2009. An Analysis of Corporate Social Responsibility (CSR) and Sustainability Reporting Assessment in the Greek Banking Sector. In Idowu S., Leal Filho W. (eds) Professionals' Perspectives of Corporate Social Responsibility, $1^{\text {st }}$ ed. Berlin: Springer Berlin Heidelberg, pp157-173. DOI: 10.1007/9783-642-02630-0_9

Fijałkowska J, Zyznarska-Dworczak B, Garsztka P. 2018. Corporate Social-Environmental Performance versus Financial Performance of Banks in Central and Eastern European Countries. Sustainability 10(3): 772. DOI: 10.3390/su10030772

Forcadell FJ, Aracil E. 2017. European Banks' Reputation for Corporate Social Responsibility. Corporate Social Responsibility and Environmental Management 24: 114. DOI: $10.1002 / \mathrm{csr} .1402$

Gara A. 2018. Forbes Top 2000: The World's largest banks in 2018 and why they still rule the world. [online] Available at: https://www.forbes.com/sites/antoinegara/2018/06/06/forbes-global-2000-the-worldslargest-banks/ [Accessed $15^{\text {th }}$ Dec. 2018].

Global Reporting Initiative, (2013). G4 Sustainability Reporting Guidelines [pdf] Available at: https://www.globalreporting.org/information/g4/Pages/default.aspx [Accessed 30 Apr. 2018]

Global Reporting Initiative. 2016. Sustainability Discosure Database [online] Available at: http://database.globalreporting.org/ [Accessed 30 ${ }^{\text {th }}$ Apr. 2018].

Global Reporting Initiative, United Nations Global Compact, World Business Council for Sustainable Development. 2015. SDG Compass; Linking the SDGs and GRI. [online] Available at: https://www.globalreporting.org/resourcelibrary/SDG_GRI_G4_LInkage. pdf [Accessed 30 ${ }^{\text {th }}$ Apr. 2018].

Global Reporting Initiative, United Nations Global Compact, World Business Council for Sustainable Development. 2017. SDG Compass; Linking the SDGs and GRI. [online] Available at: https://www.globalreporting.org/standards/resource-download-center/sdgcompass-annex-linking-the-sdgs-and-gri-standards/ [Accessed $30^{\text {th }}$ Apr. 2018]. 
Global Reporting Initiative, United Nations Global Compact, World Business Council for Sustainable Development. 2017. SDG Compass; Inventory of Business Indicators. [online] Available at: https://sdgcompass.org/business-indicators/ [Accessed 30 ${ }^{\text {th }}$ Apr. 2018].

Halkos G, Skouloudis A. 2016. Exploring the current status and key determinants of corporate disclosure on climate change: Evidence from the Greek business sector. Environmental Science and Policy 56(February): 22-31.

Hajer M, Nilsson M, Raworth K, Bakker P, Berkhout F, de Boer Y, Rockström J, Ludwig K, Kok M. 2015. Beyond cockpit-ism: Four insights to enhance the transformative potential of the sustainable development goals. Sustainability 7(2): 1651-1660. DOI: $10.3390 /$ su 7021651

Howard-Grenville J, Davis J, Dyllick T, Joshi A, Miller C, Thau S, Tsui AS. 2017. Sustainable Development for a Better World: Contributions of Leadership, Management and Organizations. Academy of Management Discoveries 3(1): 107-110. DOI: 10.5465/amd.2017.0023

Jeucken M, Bouma J. 2017. The changing environment of banks. In Sustainable Banking. Bouma J, Jeucken M. Klinkers L (eds). Routledge: London.

Koellner T, Weber O, Fenchel M, Scholz R. 2005. Principles for sustainability rating of investment funds. Business Strategy and the Environment 14(1): 54-70. DOI: $10.1002 /$ bse. 423

Kolk A, Kourula A, Pisani N, Westermann-Behaylo M, Worring M. 2018. Embracing the Un Sustainable Development Goals? Big Data Analysis of Changes in the Corporate Sustainability Agenda. Academy of Management Global Proceedings. 51.

Kumar S, Kumar N, Vivekadhish S. 2016. Millennium Development Goals (MDGs) to Sustainable Development Goals (SDGs): Addressing Unfinished Agenda and Strengthening Sustainable Development and Partnership. Indian Journal of Community Medicine 41 (1): 1-4. DOI: 10.4103/0970-0218.170955

MacQueen N. 2018. The Sins of the Fathers? From League of Nations Mandates to United Nations Peacekeeping. International Peacekeeping journal 25(1): 154-159. DOI: 10.1080/13533312.2017.1392858

Matten D, Moon J. 2008. "Implicit" and "explicit" CSR: A conceptual framework for a comparative understanding of corporate social responsibility. Academy of management Review 33(2): 404-424. DOI: 10.5465/amr.2008.31193458 
Morhardt JE, Baird S, Freeman K. 2002. Scoring corporate environmental and sustain-ability reports using GRI2000, ISO14031 and other criteria. Corporate Social Responsibility and Environmental Management 9(4): 215-233. DOI: 10.1002/csr.26

Miralles- Quiros MM, Miralles- Quiros JL, Arraiano IG. 2017. Are firms that contribute to sustainable development valued by investors? Corporate Social Responsibility and Environmental Management 24(1): 71-84. DOI: 10.1002/csr.1392

Nilsson M, Griggs D, Visbeck M. (2016) Policy: Map the interactions between Sustainable Development Goals. Nature 534(7607): 320-322. DOI: 10.1038/534320a

Pillai KV, Slutsky P, Wolf K, Duthler G, Stever I. 2017. Companies' Accountability in Sustainability: A Comparative Analysis of SDGs in Five Countries. In Sustainable Development Goals in the Asian Context, Servaes J, (eds). Springer: Singapore.

PricewaterhouseCoopers. 2017. SDG Reporting Challenge 2017 Exploring business communication on the global goals. Available at: https://www.pwc.com/gx/en/sustainability/SDG/pwc-sdg-reporting-challenge-2017final.pdf [Accessed 30 Apr. 2018].

Raut R, Cheikhrouhou N, Kharat M. 2017. Sustainability in The Banking Industry: A Strategic Multi- Criterion Analysis. Business Strategy and the Environment 26(4): 550568. DOI: $10.1002 /$ bse. 1946

Sadowski M, Whitaker K, Buckingham F. 2010. Rate the Raters: Phase Two Taking Inventory of the Ratings Universe. [Online] SustainAbility, London, UK. Available at: https://sustainability.com/our-work/reports/rate-the-raters-phase-two/ [Accessed $30^{\text {th }}$ Apr. 2018].

Schaltegger S, Etxeberria IÁ, Ortas E. 2017. Innovating corporate accounting and reporting for sustainability-attributes and challenges. Sustainable Development 25(2): 113-122. DOI: $10.1002 / \mathrm{sd} .1666$

Schaltegger S, Wagner M. 2006. Integrative management of sustainability performance, measurement and reporting. International Journal of Accounting, Auditing and Performance Evaluation 3(1): 1-19. DOI: 10.1504/IJAAPE.2006.010098

Schurer AP, Cowtan K, Hawkins E, Mann ME, Scott V, Tett SFB. 2018. Interpretations of the Paris climate target. Nature Geoscience 11: 220-221. DOI: 10.1038/s41561-0180086-8 
Shen $\mathrm{CH}$, Wu MW, Chen TH, Fang H. 2016. To engage or not to engage in corporate social responsibility: Empirical evidence from global banking sector. Economic Modelling 55: 207-225. DOI: 10.1016/j.econmod.2016.02.007

Singh GG, Cisneros-Montemayor AM, Swartz W, Cheunga W, Guy JA, Kenny T, McOwen CJ, Asch R, Geff ert JL, Wabnitz CCC, Sumaila R, Hanichj Q, Otak Y. 2018. A rapid assessment of co-benefits and trade-offs among Sustainable Development Goals. Marin Policy 93: 223-231. DOI: 10.1016/j.marpol.2017.05.030

Skouloudis A, Evangelins K., Kourmousis F. 2009. Development of an evaluation methodology for triple bottom line reports using international standards on reporting. Environmental Management 44: 298-311. DOI: 10.1007/s00267-009-9305-9

Skouloudis A, Evangelinos K, Kourmousis F. 2010. Assessing non-financial reports according to the Global Reporting Initiative guidelines: evidence from Greece. Journal of Cleaner Production 18(5): 426-438. DOI: 10.1016/j.jclepro.2009.11.015

Skouloudis A, Evangelinos K, Moraitis S. 2011. Accountability and stakeholder engagement in the airport industry: An assessment of airports' CSR reports. Journal of Air Transport Management 18(1): 16-20. DOI: 10.1016/j.jairtraman.2011.06.001

Stafford-Smith M, Griggs D, Gaffney O, Ullah F, Reyers B, Kanie N, Stigson B, Shrivastava, P, Leach M, O'Connell D. 2017. Integration: the key to implementing the Sustainable Development Goals. Sustainability Science 12(6): 911-919. DOI: 10.1007/s11625-0160383-3

Storey M, Killian S, O'Regan P. 2017. Responsible management education: mapping the field in the context of the SDGs. The International Journal of Management Education 15: 93-103. DOI: 10.1016/j.ijme.2017.02.009

United Nations. 2014. World Investment Report 2014: Investing in the SDGs - An Action Plan. United Nations conference on trade and development. [online] New York and Geneva. United Nations Publication. Available at: unctad.org/en/PublicationsLibrary/wir2014_en.pdf [Accessed 30 Apr. 2018].

United Nations. 2015a. 'We Are the First Generation that Can End Poverty, the Last that Can End Climate Change', Secretary-General Stresses at University Ceremony. [online] Available at: https://www.un.org/press/en/2015/sgsm16800.doc.htm [Accessed 30 Apr. 2018].

United Nations. 2015b. Transforming our world: the 2030 Agenda for Sustainable Development. [online] Available at: http://www.un.org/ga/search/view_doc.asp? symbol=A/RES/70/1\&Lang=E [Accessed 30 Apr. 2018]. 
United Nations Environment Programme, 2018. UN Environment and 28 Banks launch public consultation on principles for responsible banking. [online] Available at: https://www.unenvironment.org/news-and-stories/press-release/un-environment-and-28banks-launch-public-consultation-principles [Accessed 30 Dec. 2018]

United Nations Global Compact. 2017. 2017 United Nations Global Compact Progress Report: Business Solutions to Sustainable Development. [online] Available at: https://www.unglobalcompact.org/docs/publications/UN\%20Impact\%20Brochure_Conc ept-FINAL.pdf [Accessed 30 Apr. 2018].

United Nations Global Compact and KPMG International. 2015. SDG Industry Matrix; Financial Services. [online] Available at: https://www.unglobalcompact.org/docs/issues_doc/development/SDGMatrix_FinancialS vcs.pdf [Accessed 30 Apr. 2018].

Van Marrewijk M. 2003. Concepts and definitions of CSR and corporate sustainability: Between agency and communion. Journal of Business Ethics 44(2-3): 95-105. DOI: 10.1023/A:1023331212247

Venturelli A, Cosma S, Leopizzi R. 2018. Stakeholder Engagement: An Evaluation of European Banks. Corporate Social Responsibility and Environmental Management 25(4): 690-703. DOI: 10.1002/csr.1486

Weber O. 2005. Sustainability benchmarking of European banks and financial service organizations. Corporate Social Responsibility and Environmental Management 12(2): 73-87. DOI: $10.1002 / \mathrm{csr} .77$

Weber O, Diaz M, Schwegler R. 2014. Corporate Social Responsibility of the Financial Sector- Strengths, Weakness and Impact on Sustainable Development. Sustainable Development 22(5): 321-335. DOI: 10.1002/sd.1543

World Business Council for Sustainable Development. 2002. Sustainable Development Reporting: Striking the Balance. [online] Available at: http://wbcsdservers.org/wbcsdpublications/cd_files/datas/financial_capital/reporting_inv estment/pdf/SustainableDevReporting-Striking-the-balance.pdf $\left[\right.$ Accessed $30^{\text {th }}$ Apr. 2018].

$\mathrm{Wu}$ M, Shen $\mathrm{CH}$. 2013. Corporate social responsibility in the banking industry: Motives and financial performance. Journal of Banking \& Finance 37(9): 3529-3547. DOI: 10.1016/j.jbankfin.2013.04.023

Xiao Y, Norris CB, Lenzen M, Norris G, Murray J. 2017. How social footprints of nations can assist in achieving the Sustainable Development Goals. Ecological economics 135(C):55-65. DOI:10.1016/j.ecolecon.2016.12.003 
Yongvanich K, Guthrie J. 2006. An extended performance reporting framework for social and environmental accounting. Journal of Business Strategy and the Environment 15 (5): 309-321. DOI: 10.1002/bse.541

Zimmern A. 1936. The League of Nations and the rule of law, 1918-1935. International Journal of Ethics $47 \quad(1): 122-124 . \quad$ DOI: $\quad \underline{10.1086 / 208353}$ 
Table 1: Sample Banks, classifications and 2016 annual reports

\begin{tabular}{|c|c|c|c|c|c|c|c|c|}
\hline Bank & $\begin{array}{l}\text { DJSI } \\
\text { classifi } \\
\text { caltion }\end{array}$ & Country & Site & $\begin{array}{l}\text { Sustainability } \\
\text { Report title }\end{array}$ & Additional References Reviewed $\dagger$ & Size & $\begin{array}{l}\text { Employees } \\
\text { at Group } \\
\text { level }(, 000)\end{array}$ & $\begin{array}{c}\text { Market } \\
\text { Capitalisation } \\
\text { of the Group } \\
(€ \text { bn })\end{array}$ \\
\hline $\begin{array}{l}\text { B1: Skandinaviska } \\
\text { Enskilda Banken AB } \\
\text { (SEB) }\end{array}$ & Brown & Sweden & $\begin{array}{l}\text { https://sebgroup. } \\
\underline{\text { com }}\end{array}$ & $\begin{array}{l}2016 \\
\text { Sustainability } \\
\text { Report }\end{array}$ & $\begin{array}{l}\text { Sustainability Fact Book and GRI index, } \\
\text { Code of Conduct. }\end{array}$ & Large & 16 & 22 \\
\hline $\begin{array}{l}\text { B2: } \\
\text { Banco Santander SA }\end{array}$ & Silver & Spain & $\underline{\text { https://www.san }}$ & $\begin{array}{l}\text { Sustainability } \\
\text { Report } 2016\end{array}$ & $\begin{array}{l}\text { Auditors' report and annual consolidated accounts, } \\
\text { Consolidated Directors' Report, Annual corporate } \\
\text { governance report, Santander Group General Code of } \\
\text { Conduct, Report of the Committees- Report of the } \\
\text { Remuneration Committee. }\end{array}$ & Large & 188 & 72 \\
\hline B3: CaixaBank SA & Brown & Spain & $\begin{array}{l}\underline{\text { https://www.cai }} \\
\underline{\text { xabank.com }}\end{array}$ & $\begin{array}{l}\text { Integrated } \\
\text { Corporate } \\
\text { Report } 2016\end{array}$ & $\begin{array}{l}\text { 2016Socioeconomic Impact Report, CaixaBank Group } \\
\text { Statutory Documentation 2016, } 2016 \text { Consolidated } \\
\text { Financial Statements, } 2016 \text { Annual Corporate Governance } \\
\text { Report, CaixaBank Code of Business Conduct and Ethics, } \\
\text { Regulations of the Board of Directors, Corporate Social } \\
\text { Responsibility Policy, } 2016 \text { Annual Report on Directors' } \\
\text { Remuneration. }\end{array}$ & Large & 32 & 19 \\
\hline $\begin{array}{l}\text { B4: Intesa Sanpaolo } \\
\text { SpA }\end{array}$ & Brown & Italy & $\begin{array}{l}\underline{\text { https://www.inte }} \\
\underline{\text { sasanpaolo.com }}\end{array}$ & $\begin{array}{l}\text { Sustainability } \\
\text { Report } 2016\end{array}$ & $\begin{array}{l}\text { Report on Corporate Governance and Ownership } \\
\text { Structures Report on Remuneration, Intesa Sanpaolo } \\
\text { "Carbon Disclosure Project" questionnaire, Report and } \\
\text { consolidated financial statements of the Intesa Sanpaolo } \\
\text { Group as at } 31 \text { December 2016, Code of ethics. }\end{array}$ & Large & 89 & 41 \\
\hline B5: BNP Paribas SA & Brown & France & $\frac{\text { https://group.bn }}{\text { pparibas/en }}$ & $\begin{array}{l}2016 \text { Report } \\
\text { on Activity } \\
\text { and Corporate } \\
\text { Responsibility }\end{array}$ & $\begin{array}{l}\text { Registration Document and Annual Financial Report 2016, } \\
\text { BNP Paribas Supplier's CSR Charter, The BNP Paribas } \\
\text { group Code of Conduct. }\end{array}$ & Large & 192 & 76 \\
\hline
\end{tabular}

$\dagger$ Data sources included in the assessment in addition to the sustainability report documentation and were reviewed, according to pertinent,

location-specific, references in the GRI Contents Index.

$\$$ Large Enterprise: Headcount $>=250$, Turnover $>€ 50$ million or Balance sheet total $>€ 43$ million 
Table 2: Number of Business themes and GRI Indicators per SDGs

\begin{tabular}{|l|c|c|}
\hline SDG & $\begin{array}{c}\text { Number of } \\
\text { Business Themes }\end{array}$ & $\begin{array}{c}\text { Number of GRI } \\
\text { Indicators }\end{array}$ \\
\hline 1. No Poverty & 6 & 10 \\
\hline 2. Zero Hunger & 4 & 5 \\
\hline 3. Good Health and Well-being & 5 & 11 \\
\hline 4. Quality Education & 2 & 2 \\
\hline 5. Gender Equality & 8 & 16 \\
\hline 6. Clean Water and Sanitation & 7 & 15 \\
\hline 7. Affordable and Clean Energy & 4 & 10 \\
\hline 8. Decent Work and Economic Growth & 24 & 43 \\
\hline 9. Industry, Innovation and Infrastructure & 4 & 7 \\
\hline 10. Reduced Inequalities & 5 & 16 \\
\hline 11. Sustainable Cities and Communities & 3 & 3 \\
\hline 12. Responsible, Consumption and Production & 12 & 24 \\
\hline 13. Climate Action & 4 & 14 \\
\hline 14. Life Below Water & 5 & 15 \\
\hline 15. Life on Land & 5 & 19 \\
\hline 16. Peace, Justice, and Strong Institutions & 11 & 2 \\
\hline 17. Partnerships for the Goals & 2 & 244 \\
\hline Total & 111 & 71 \\
\hline Total individual Business Themes/ GRI Indicators & 68 & \\
\hline
\end{tabular}

Source: developed by authors 
Table 3: Overview of reporting performance for all banks across SDGs criteria

\begin{tabular}{|c|c|c|c|c|c|c|c|c|c|c|c|c|c|c|c|c|c|c|c|}
\hline \multirow{2}{*}{ BANK } & \multicolumn{17}{|c|}{ SDGs } & \multirow{2}{*}{$\begin{array}{c}\text { Mean } \\
\text { Reporting } \\
\text { Performance }\end{array}$} & \multirow{2}{*}{$\begin{array}{l}\text { Standard } \\
\text { Deviation }\end{array}$} \\
\hline & 1 & 2 & 3 & 4 & 5 & 6 & 7 & 8 & 9 & 10 & 11 & 12 & 13 & 14 & 15 & 16 & 17 & & \\
\hline B1 & 0.30 & 0.38 & 0.64 & 0.00 & 0.45 & 0.29 & 0.28 & 1.08 & 0.25 & 0.28 & 0.33 & 0.22 & 0.49 & 0.23 & 0.23 & 0.73 & 0.00 & 0.36 & 0.26 \\
\hline $\mathrm{B} 2$ & 1.83 & 1.38 & 1.58 & 1.50 & 1.00 & 0.19 & 0.40 & 1.18 & 0.38 & 0.83 & 1.67 & 0.94 & 0.65 & 0.34 & 0.34 & 1.35 & 0.00 & 0.91 & 0.58 \\
\hline B3 & 0.33 & 0.00 & 0.10 & 4.00 & 1.13 & 0.05 & 0.00 & 1.42 & 0.38 & 1.04 & 1.00 & 0.13 & 0.57 & 0.06 & 0.06 & 1.46 & 0.00 & 0.69 & 1.00 \\
\hline B4 & 0.90 & 0.63 & 1.98 & 3.50 & \begin{tabular}{|l|l|} 
\\
\end{tabular} & 0.62 & 1.40 & 1.70 & 1.63 & 1.87 & 2.00 & 1.28 & 2.79 & 0.97 & 0.97 & 1.47 & 1.00 & 1.56 & 0.76 \\
\hline B5 & 0.03 & 0.63 & 0.44 & 2.50 & 0.42 & 0.05 & 0.35 & 0.53 & 0.13 & 0.07 & 0.00 & 0.12 & 0.26 & 0.17 & 0.17 & 0.23 & 0.00 & 0.36 & 0.58 \\
\hline TOTAL & 0.68 & 0.60 & 0.95 & 2.30 & 0.95 & 0.24 & 0.49 & 1.18 & 0.55 & 0.82 & 1.00 & 0.54 & 0.95 & 0.35 & 0.35 & 1.05 & 0.20 & 0.78 & 0.49 \\
\hline
\end{tabular}

Source: developed by authors 
Table 4: Top 7 and Bottom 7 SDG criteria and their scores

\begin{tabular}{|c|c|c|c|c|}
\hline \multirow{2}{*}{ Rank } & \multicolumn{2}{|c|}{ Top 7 } & \multicolumn{2}{c|}{ Bottom 7 } \\
\cline { 2 - 5 } & SDGs & Score & SDGs & Score \\
\hline 1 & 4 & 2.30 & 17 & 0.20 \\
\hline 2 & 8 & 1.18 & 6 & 0.24 \\
\hline 3 & 16 & 1.05 & 15 & 0.35 \\
\hline 4 & 11 & 1.00 & 14 & 0.35 \\
\hline 5 & 13 & 0.95 & 7 & 0.49 \\
\hline 6 & 3 & 0.95 & 12 & 0.54 \\
\hline 7 & 5 & 0.95 & 9 & 0.55 \\
\hline
\end{tabular}

Source: developed by authors 
Table 5: Overview of SDGs contribution according to Banks' claim and this study

\begin{tabular}{|c|c|c|c|c|c|c|c|c|c|c|c|c|c|c|c|c|c|}
\hline \multirow{2}{*}{ BANK } & \multicolumn{17}{|c|}{ SDGs } \\
\hline & 1 & 2 & 3 & 4 & 5 & 6 & 7 & 8 & 9 & 10 & 11 & 12 & 13 & 14 & 15 & 16 & 17 \\
\hline B1 & $\mathrm{X}$ & $\mathrm{X}$ & $\mathrm{X}$ & $\checkmark$ & $\begin{array}{l}X \\
\checkmark\end{array}$ & $\begin{array}{l}X \\
\checkmark\end{array}$ & $\mathrm{X}$ & $\begin{array}{l}X \\
\checkmark\end{array}$ & $\begin{array}{l}x \\
\checkmark\end{array}$ & $\mathrm{X}$ & $\mathrm{X}$ & $\mathrm{X}$ & $\begin{array}{l}X \\
\checkmark\end{array}$ & $\mathrm{X}$ & $\mathrm{X}$ & $\begin{array}{l}\mathrm{X} \\
\checkmark\end{array}$ & $\checkmark$ \\
\hline B2 & $\mathrm{X}$ & $\mathrm{X}$ & $\begin{array}{l}x \\
\checkmark\end{array}$ & $\begin{array}{l}X \\
\checkmark\end{array}$ & $\begin{array}{l}X \\
\checkmark\end{array}$ & $\mathrm{X}$ & $\mathrm{X}$ & $\begin{array}{l}X \\
\checkmark\end{array}$ & $\mathrm{X}$ & $\begin{array}{l}X \\
\checkmark\end{array}$ & $\begin{array}{l}X \\
\checkmark\end{array}$ & $\begin{array}{l}\mathrm{X} \\
\checkmark\end{array}$ & $\begin{array}{l}X \\
\checkmark\end{array}$ & $\mathrm{X}$ & $\mathrm{X}$ & $\mathrm{X}$ & \\
\hline B3 & $\begin{array}{l}X \\
\checkmark\end{array}$ & $\checkmark$ & $\begin{array}{l}X \\
\checkmark\end{array}$ & $\begin{array}{l}x \\
\checkmark\end{array}$ & $\mathrm{X}$ & $\begin{array}{l}X \\
\checkmark\end{array}$ & $\checkmark$ & $\begin{array}{l}X \\
\checkmark\end{array}$ & $\begin{array}{l}X \\
\checkmark\end{array}$ & $\begin{array}{l}\mathrm{X} \\
\checkmark\end{array}$ & $\mathrm{X}$ & $\mathrm{X}$ & $\begin{array}{l}\mathrm{X} \\
\checkmark\end{array}$ & $\begin{array}{l}\mathrm{X} \\
\checkmark\end{array}$ & $\begin{array}{l}\mathrm{X} \\
\checkmark\end{array}$ & $\begin{array}{l}\mathrm{X} \\
\checkmark\end{array}$ & \\
\hline B4 & $\begin{array}{l}x \\
\checkmark\end{array}$ & $\begin{array}{l}x \\
\checkmark\end{array}$ & $\begin{array}{l}x \\
\checkmark\end{array}$ & $\begin{array}{l}x \\
\checkmark\end{array}$ & $\begin{array}{l}X \\
\checkmark\end{array}$ & $\begin{array}{l}X \\
\checkmark\end{array}$ & $\begin{array}{l}X \\
\checkmark\end{array}$ & $\begin{array}{l}X \\
\checkmark\end{array}$ & $\begin{array}{l}x \\
\checkmark\end{array}$ & $\begin{array}{l}X \\
\checkmark\end{array}$ & $\begin{array}{l}X \\
\checkmark\end{array}$ & $\begin{array}{l}\mathrm{X} \\
\checkmark\end{array}$ & $\begin{array}{l}X \\
\checkmark\end{array}$ & $\begin{array}{l}\mathrm{X} \\
\checkmark\end{array}$ & $\begin{array}{l}\mathrm{X} \\
\checkmark\end{array}$ & $\begin{array}{l}\mathrm{X} \\
\checkmark\end{array}$ & $\mathrm{X}$ \\
\hline B5 & $\begin{array}{l}x \\
\checkmark\end{array}$ & $\begin{array}{l}x \\
\checkmark\end{array}$ & $\begin{array}{l}x \\
\checkmark\end{array}$ & $\begin{array}{l}x \\
\checkmark\end{array}$ & $\begin{array}{l}X \\
\checkmark\end{array}$ & $\begin{array}{l}X \\
\checkmark\end{array}$ & $\begin{array}{l}X \\
\checkmark\end{array}$ & $\begin{array}{l}X \\
\checkmark\end{array}$ & $\begin{array}{l}x \\
\checkmark\end{array}$ & $\begin{array}{l}\mathrm{X} \\
\checkmark\end{array}$ & $\checkmark$ & $\begin{array}{l}\mathrm{X} \\
\checkmark\end{array}$ & $\begin{array}{l}X \\
\checkmark\end{array}$ & $\begin{array}{l}\mathrm{X} \\
\checkmark\end{array}$ & $\begin{array}{l}\mathrm{X} \\
\checkmark\end{array}$ & $\begin{array}{l}\mathrm{X} \\
\checkmark\end{array}$ & $\checkmark$ \\
\hline
\end{tabular}

(x) according to this study $(\checkmark)$ according to bank's claim

Source: developed by authors 
Table 6: Top 10 Business themes

\begin{tabular}{|c|l|c|}
\hline \multirow{2}{*}{ Rank } & \multicolumn{2}{|c|}{ Top 10 } \\
\cline { 2 - 3 } & Business theme & Score \\
\hline 1 & Youth employment & 3.00 \\
\hline 2 & Economic performance & 2.60 \\
\hline 3 & Gender equality & 2.60 \\
\hline 4 & Protection of privacy & 2.40 \\
\hline 5 & Employee training and education & 2.23 \\
\hline 6 & Ethical and lawful behavior & 2.13 \\
\hline 7 & Women in leadership & 2.13 \\
\hline 8 & Employment & 2.07 \\
\hline 9 & Access to affordable housing & 2.00 \\
\hline 10 & Diversity and equal opportunity & 2.00 \\
\hline
\end{tabular}

Source: developed by authors 
Table 7: Top 10 GRI indicators

\begin{tabular}{|c|l|c|}
\hline \multirow{2}{*}{ Rank } & \multicolumn{2}{|c|}{ Top 10 } \\
\cline { 2 - 3 } & GRI Indicators & Mean \\
\hline 1 & G4-11 & 4.00 \\
\hline 2 & G4-56 & 3.20 \\
\hline 3 & G4-EN16 & 2.40 \\
\hline 4 & G4-10 & 2.40 \\
\hline 5 & G4-39 & 2.40 \\
\hline 6 & G4-58 & 2.40 \\
\hline 7 & G4-53 & 2.20 \\
\hline 8 & FS10 & 2.00 \\
\hline 9 & G4-43 & 2.00 \\
\hline 10 & FS7 & 1.84 \\
\hline
\end{tabular}

Source: developed by authors 
Figure 1: SDGs Score across sample banks

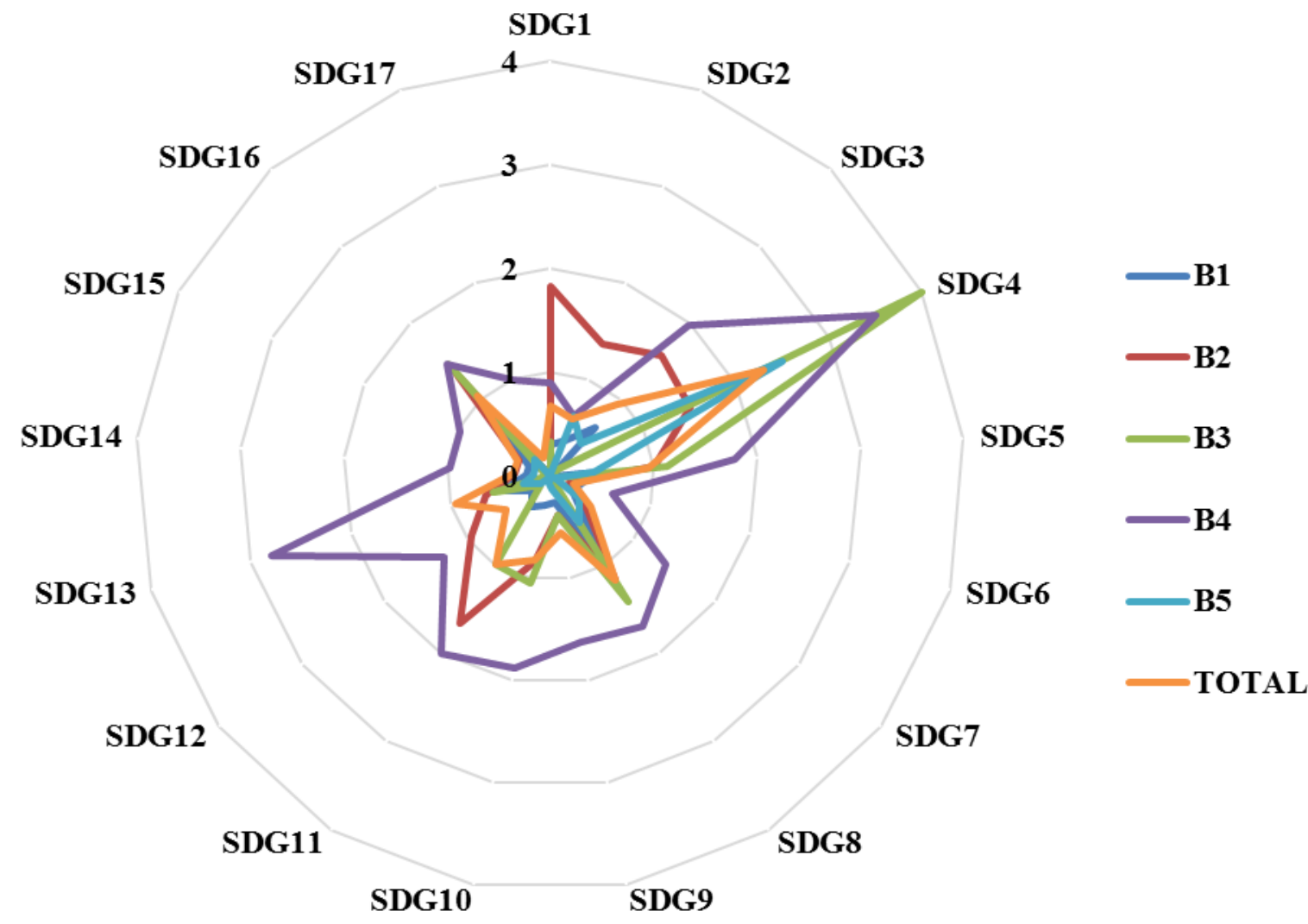




\section{APPENDICES}

\section{Appendix 1: Linking the SDGs and GRI $\dagger$}

Usage of GRI G4 and GRI G4 Financial Services Sector Disclosure:

\begin{tabular}{|c|c|c|}
\hline SDG & Business Theme & GRI Indicators \\
\hline \multirow{6}{*}{$\begin{array}{l}\text { 1. End poverty in all } \\
\text { its forms } \\
\text { everywhere }\end{array}$} & Access to financial services & FS6, FS7, FS13, FS14, former FS16 \\
\hline & Access to land & G4-SO2 \\
\hline & $\begin{array}{l}\text { Availability of products and services for } \\
\text { those on low incomes }\end{array}$ & G4-EC8 \\
\hline & Earnings, wages and benefits & G4-EC5 \\
\hline & $\begin{array}{l}\text { Economic development in areas of high } \\
\text { poverty }\end{array}$ & G4-EC8 \\
\hline & Economic inclusion & $\begin{array}{l}\text { G4-DMA-b Guidance for Procurement } \\
\text { Practices }\end{array}$ \\
\hline \multirow{4}{*}{$\begin{array}{l}\text { 2. End hunger, } \\
\text { achieve food } \\
\text { security and } \\
\text { improved nutrition } \\
\text { and promote } \\
\text { sustainable } \\
\text { agriculture }\end{array}$} & Access to land & G4-SO2 \\
\hline & $\begin{array}{l}\text { Changing the productivity of organizations, } \\
\text { sectors, or the whole economy }\end{array}$ & G4-EC8 \\
\hline & Indigenous rights & G4-HR8 \\
\hline & Infrastructure investments & G4-EC1, G4-EC7 \\
\hline \multirow{5}{*}{$\begin{array}{l}\text { 3. Ensure healthy } \\
\text { lives and promote } \\
\text { well-being for all at } \\
\text { all ages }\end{array}$} & Access to medicines & G4-EC8 \\
\hline & Air quality & $\begin{array}{l}\text { G4-EN15, G4-EN16, G4-EN17, } \\
\text { G4-EN20, G4-EN21 }\end{array}$ \\
\hline & Occupational health and safety & G4-LA6, G4-LA7 \\
\hline & Spills & G4-EN2 \\
\hline & Waste & G4-EN23, G4-EN25 \\
\hline \multirow{2}{*}{$\begin{array}{l}\text { 4. Ensure inclusive } \\
\text { and equitable } \\
\text { quality education } \\
\text { and promote } \\
\text { lifelong learning } \\
\text { opportunities for all }\end{array}$} & Education for sustainable development & G4-43 \\
\hline & Employee training and education & G4-LA9 \\
\hline \multirow{8}{*}{$\begin{array}{l}\text { 5. Achieve gender } \\
\text { equality and } \\
\text { empower all } \\
\text { women and girl }\end{array}$} & Economic inclusion & $\begin{array}{l}\text { G4-DMA-b Guidance for Procurement } \\
\text { Practices }\end{array}$ \\
\hline & $\begin{array}{l}\text { Equal remuneration for women } \\
\text { and men }\end{array}$ & G4-EC5, G4-LA13 \\
\hline & Gender equality & G4-LA1, G4-LA9, G4-LA11, G4-LA12 \\
\hline & Infrastructure investments & G4-EC1, G4-EC7 \\
\hline & Non-discrimination & G4-HR3 \\
\hline & Parental leave & G4-LA3 \\
\hline & Women in leadership & G4-38, G4-40, G4-LA12 \\
\hline & Workplace violence and harassment & G4-LA14, G4-LA15 \\
\hline
\end{tabular}




\begin{tabular}{|c|c|c|}
\hline SDG & Business Theme & GRI Indicators \\
\hline \multirow{7}{*}{$\begin{array}{l}\text { 6. Ensure } \\
\text { availability and } \\
\text { sustainable } \\
\text { management of } \\
\text { water and sanitation } \\
\text { for all }\end{array}$} & Spills & G4-EN24 \\
\hline & Sustainable water withdrawals & G4-EN8, G4-EN9, G4-EN27 \\
\hline & Waste & G4-EN23 \\
\hline & Water efficiency & G4-EN10 \\
\hline & Water quality & G4-EN22 \\
\hline & Water recycling and reuse & G4-EN10 \\
\hline & Water-related ecosystems and biodiversity & $\begin{array}{l}\text { G4-EN11, G4-EN12, G4-EN13, G4- } \\
\text { EN14, } \\
\text { G4-EN22, G4-EN24, G4-EN26 }\end{array}$ \\
\hline \multirow{4}{*}{$\begin{array}{l}\text { 7. Ensure access to } \\
\text { affordable, reliable, } \\
\text { sustainable and } \\
\text { modern energy for } \\
\text { all }\end{array}$} & Energy efficiency & $\begin{array}{l}\text { G4-EN3, G4-EN4, G4-EN5, G4-EN6, } \\
\text { G4-EN7 }\end{array}$ \\
\hline & Environmental investments & G4-EN31 \\
\hline & Infrastructure investments & G4-EC1, G4-EC7 \\
\hline & Renewable energy & G4-EN3, G4-EN4 \\
\hline \multirow{22}{*}{$\begin{array}{l}\text { 8. Promote } \\
\text { sustained, inclusive } \\
\text { and sustainable } \\
\text { economic growth, } \\
\text { full and productive } \\
\text { employment and } \\
\text { decent work for all }\end{array}$} & Abolition of child labor & G4-HR5 \\
\hline & Access to financial services & FS6, FS7, FS13, FS14, former FS16 \\
\hline & $\begin{array}{l}\text { Changing the productivity of organizations, } \\
\text { sectors, or the whole economy }\end{array}$ & G4-EC8 \\
\hline & Diversity and equal opportunity & G4-LA12 \\
\hline & Earnings, wages and benefits & G4-EC5, G4-LA2 \\
\hline & Economic inclusion & $\begin{array}{l}\text { G4-DMA-b Guidance for Procurement } \\
\text { Practices }\end{array}$ \\
\hline & Economic performance & G4-EC1 \\
\hline & Elimination of forced or compulsory labor & G4-HR6 \\
\hline & Employee training and education & G4-LA9, G4-LA10, G4-LA11 \\
\hline & Employment & G4-10, G4-EC6, G4-LA1 \\
\hline & Energy efficiency & $\begin{array}{l}\text { G4-EN3, G4-EN4, G4-EN5, G4-EN6, } \\
\text { G4-EN7 }\end{array}$ \\
\hline & Equal remuneration for women and men & G4-LA13 \\
\hline & $\begin{array}{l}\text { Freedom of association and collective } \\
\text { bargaining }\end{array}$ & G4-11, G4-HR4 \\
\hline & Indirect impact on job creation & G4-EC8 \\
\hline & Jobs supported in the supply chain & G4-EC8 \\
\hline & Labor practices in the supply chain & G4-LA14 and G4-LA15 \\
\hline & Labor/management relations & G4-LA4 \\
\hline & Materials efficiency & G4-EN1, G4-EN2 \\
\hline & Non-discrimination & G4-HR3 \\
\hline & Occupational health and safety & G4-LA5, G4-LA6, G4-LA7, G4-LA8 \\
\hline & Parental leave & G4-LA3 \\
\hline & Resource efficiency of products and & G4-EN27, G4-EN28 \\
\hline
\end{tabular}




\begin{tabular}{|c|c|c|}
\hline & services & \\
\hline & Water efficiency & G4-EN10 \\
\hline & Youth employment & G4-LA1 \\
\hline SDG & Business Theme & GRI Indicators \\
\hline & Access to financial services & FS6, FS7 \\
\hline infrastructure, & Environmental investments & G4-EN31 \\
\hline and sustainable & Infrastructure investments & G4-EC1, G4-EC7 \\
\hline foster innovation & Research and development & G4-EC1, G4-EN31 \\
\hline & Access to financial services & FS7, FS13, FS14, former FS16 \\
\hline & $\begin{array}{l}\text { Economic development in areas } \\
\text { of high poverty }\end{array}$ & G4-EC8 \\
\hline $\begin{array}{l}\text { 10. Reduce } \\
\text { inequality } \\
\text { within and among }\end{array}$ & $\begin{array}{l}\text { Equal remuneration for women } \\
\text { and men }\end{array}$ & G4-LA13 \\
\hline countries & Foreign direct investment & G4-EC8 \\
\hline & Responsible finance & $\begin{array}{l}\text { FS10, FS11, former FS1, former FS2, } \\
\text { former FS3, former FS4, former FS5, } \\
\text { former FS9, former FS15 }\end{array}$ \\
\hline $\begin{array}{l}\text { 11. Make cities and } \\
\text { human settlements }\end{array}$ & Access to affordable housing & FS7 \\
\hline inclusive, safe, & Infrastructure investments & G4-EC7 \\
\hline sustainable & Sustainable transportation & G4-EN30 \\
\hline & Air quality & $\begin{array}{l}\text { G4-EN15, G4-EN16, G4-EN17, G4- } \\
\text { EN20, G4-EN21 }\end{array}$ \\
\hline & Energy efficiency & $\begin{array}{l}\text { G4-EN3, G4-EN4, G4-EN5, G4-EN6, } \\
\text { G4-EN7 }\end{array}$ \\
\hline & Environmental investments & G4-EN31 \\
\hline & Materials efficiency/recycling & G4-EN1, G4-EN2 \\
\hline 12. Ensure & Procurement practices & G4-EC9 \\
\hline $\begin{array}{l}\text { sustainable } \\
\text { consumption }\end{array}$ & $\begin{array}{l}\text { Product and service information and } \\
\text { labeling }\end{array}$ & G4-PR3 \\
\hline patterns & $\begin{array}{l}\text { Resource efficiency of products and } \\
\text { services }\end{array}$ & G4-EN27, G4-EN28 \\
\hline & Spills & G4-EN24 \\
\hline & Transport & G4-EN30 \\
\hline & Waste & G4-EN23, G4-EN25, G4-EN27 \\
\hline & Water efficiency & G4-EN10 \\
\hline & Water quality & G4-EN22 \\
\hline 13. Take urgent & Energy efficiency & $\begin{array}{l}\text { G4-EN3, G4-EN4, G4-EN5, G4-EN6, } \\
\text { G4-EN7 }\end{array}$ \\
\hline $\begin{array}{l}\text { action to combat } \\
\text { climate change }\end{array}$ & Environmental investments & G4-EN31 \\
\hline and its impacts* & GHG emissions & $\begin{array}{l}\text { G4-EN15, G4-EN16, G4-EN17, G4- } \\
\text { EN18, }\end{array}$ \\
\hline
\end{tabular}




\begin{tabular}{|c|c|c|}
\hline & & G4-EN19, G4-EN27, G4-EN30 \\
\hline & $\begin{array}{l}\text { Risks and opportunities due } \\
\text { to climate change }\end{array}$ & G4-EC2 \\
\hline SDG & Business Theme & GRI Indicators \\
\hline & Environmental investments & G4-EN31 \\
\hline $\begin{array}{l}\text { 14. Conserve and } \\
\text { sustainably use } \\
\text { the oceans, }\end{array}$ & Marine biodiversity & $\begin{array}{l}\text { G4-EN11, G4-EN12, G4-EN13, } \\
\text { G4-EN14, G4-EN26 }\end{array}$ \\
\hline $\begin{array}{l}\text { seas and marine } \\
\text { resources for }\end{array}$ & Ocean acidification & $\begin{array}{l}\text { G4-EN15, G4-EN16, G4-EN17, G4- } \\
\text { EN18, G4-EN19, G4-EN21, G4-EN27 }\end{array}$ \\
\hline $\begin{array}{l}\text { Sustainabie } \\
\text { development }\end{array}$ & Spills & G4-EN24 \\
\hline & Water discharge to oceans & G4-EN22 \\
\hline 15. Protect, restore & Environmental investments & G4-EN31 \\
\hline $\begin{array}{l}\text { sustainable use } \\
\text { of terrestrial }\end{array}$ & Forest degradation & $\begin{array}{l}\text { G4-EN15, G4-EN16, G4-EN17, G4- } \\
\text { EN18, G4-EN19, G4-EN21, G4-EN27 }\end{array}$ \\
\hline $\begin{array}{l}\text { ecosystems, } \\
\text { sustainably } \\
\text { manage }\end{array}$ & Natural habitat degradation & $\begin{array}{l}\text { G4-EN11, G4-EN12, G4-EN13, } \\
\text { G4-EN14, G4-EN26 }\end{array}$ \\
\hline $\begin{array}{l}\text { forests, combat } \\
\text { desertification }\end{array}$ & Spills & G4-EN24 \\
\hline $\begin{array}{l}\text { and halt and } \\
\text { reverse land } \\
\text { degradation and } \\
\text { halt biodiversity } \\
\text { loss }\end{array}$ & $\begin{array}{l}\text { Terrestrial and inland freshwater } \\
\text { ecosystems }\end{array}$ & $\begin{array}{l}\text { G4-EN11, G4-EN12, G4-EN13, } \\
\text { G4-EN14, G4-EN26 }\end{array}$ \\
\hline & Abolition of child labor & G4-HR5 \\
\hline & Anti-corruption & G4-SO3, G4-SO4, G4-SO5, G4-SO6 \\
\hline $\begin{array}{l}\text { 16. Promote } \\
\text { peaceful }\end{array}$ & Compliance with laws and regulations & $\begin{array}{l}\text { G4-EN29, G4-SO7, G4-SO8, G4-PR2, } \\
\text { G4-PR4, G4-PR7, G4-PR8, G4-PR9 }\end{array}$ \\
\hline $\begin{array}{l}\text { and inclusive } \\
\text { societies for } \\
\text { sustainable }\end{array}$ & $\begin{array}{l}\text { Effective, accountable and transparent } \\
\text { governance }\end{array}$ & G4-39, G4-41 \\
\hline development, & Ethical and lawful behavior & G4-56, G4-57, G4-58 \\
\hline $\begin{array}{l}\text { justice for all and } \\
\text { build effective, }\end{array}$ & Grievance mechanisms & $\begin{array}{l}\text { G4-EN34, G4-LA16, G4-HR12, } \\
\text { G4-SO11 }\end{array}$ \\
\hline accountable & Inclusive decision making & G4-37, G4-38, G4-40, G4-45, G4-53 \\
\hline institutions at & Non-discrimination & G4-HR3 \\
\hline all levels & Protection of privacy & G4-PR8 \\
\hline & Security & G4-HR7 \\
\hline & Workplace violence and harassment & G4-LA14, G4-LA15 \\
\hline $\begin{array}{l}\text { 17. Strengthen } \\
\text { the means of } \\
\text { implementation } \\
\text { and revitalize the }\end{array}$ & Environmental investments & G4-EN31 \\
\hline $\begin{array}{l}\text { global partnersnip } \\
\text { for sustainable } \\
\text { development }\end{array}$ & Foreign direct investment & G4-EC8 \\
\hline
\end{tabular}


$\dagger$ Based on the SDG Compass 'Linking the SDGs and GRI' (GRI, UN Global Compact, WBCSD, 2015).

\$ Indicators from the GRI G4 Financial Sector Disclosures are highlighted in blue.

Appendix 2: Most-frequently disclosed GRI indicators

\begin{tabular}{|c|c|c|c|}
\hline \multirow{2}{*}{ Rank } & \multicolumn{3}{|c|}{ Top 23} \\
\hline & GRI indicators ${ }^{\dagger}$ & Frequency & SDGs correspondence \\
\hline 1 & G4-EC8 & 10 & $1,2,3,8,10,17$ \\
\hline 2 & G4-EN31 & 8 & $7,9,12,13,14,15,17$ \\
\hline 3 & G4-EN27 & 7 & $6,8,12,13,14,15$ \\
\hline 4 & G4-EC1 & 6 & $2,5,7,8,9$ \\
\hline 5 & \begin{tabular}{|l} 
G4-EN16 \\
\end{tabular} & 5 & $3,12,13,14,15$ \\
\hline 6 & FS7 & 5 & $1,8,9,10,11$ \\
\hline 7 & G4-EN3 & 5 & $7,8,12,13$ \\
\hline 8 & G4-EN15 & 5 & $3,12,13,14,15$ \\
\hline 9 & G4-EN17 & 5 & $3,12,13,14,15$ \\
\hline 10 & G4-EN4 & 5 & $7,8,12,13$ \\
\hline 11 & G4-EC7 & 5 & $2,5,7,9,11$ \\
\hline 12 & \begin{tabular}{|l|} 
G4-EN24 \\
\end{tabular} & 5 & $6,12,14,15$ \\
\hline 13 & G4-EN5 & 4 & $7,8,12,13$ \\
\hline 14 & G4-EN6 & 4 & $7,8,12,13$ \\
\hline 15 & G4-EN21 & 4 & $3,12,14,15$ \\
\hline 16 & \begin{tabular}{|l|} 
G4-EN7 \\
\end{tabular} & 4 & $7,8,12,13$ \\
\hline 17 & G4-EN10 & 4 & $6,8,12$ \\
\hline 18 & G4-EN11 & 4 & $6,14,15$ \\
\hline 19 & G4-EN12 & 4 & $6,14,15$ \\
\hline 20 & G4-EN13 & 4 & $6,14,15$ \\
\hline 21 & G4-EN14 & 4 & $6,14,15$ \\
\hline 22 & \begin{tabular}{|l|} 
G4-EN22 \\
\end{tabular} & 4 & $6,12,14$ \\
\hline 23 & G4-EN26 & 4 & $6,14,15$ \\
\hline
\end{tabular}

$\dagger$ Indicators from the GRI G4 Financial Sector Disclosures are highlighted in blue.

+ Number of appearance in methodology applied (Appendix 1) 
Appendix 3: List of abbreviations

\begin{tabular}{|l|l|}
\hline Abbreviations & Description \\
\hline BSC & Balanced Scorecard \\
\hline CDP & Carbon Disclosure Project \\
\hline CR & Corporate Responsibility \\
\hline CSA & Corporate Sustainability Assessment \\
\hline CSR & Corporate Social Responsibility \\
\hline DJSI & Dow Jones Sustainability Index \\
\hline EU & European Union \\
\hline FS & Financial Services \\
\hline FTSE4Good & Financial Times Stock Exchange for Good Index \\
\hline GDP & Gross domestic product \\
\hline GRI & Global Reporting Initiative \\
\hline IC & Intellectual Capital \\
\hline KPI & Key Performance Indicator \\
\hline MDGs & Millennium Development Goals \\
\hline MSCIESG & $\begin{array}{l}\text { Morgan Stanley Capital International Environmental, Social and } \\
\text { Governance Index }\end{array}$ \\
\hline PWC & PricewaterhouseCoopers \\
\hline SA & Anonymous society \\
\hline SDG & Sustainable Development Goal \\
\hline TBL & Triple Bottom Line \\
\hline UK & United Kingdom \\
\hline UN & United Nations \\
\hline UNDP & United Nations Development Programme \\
\hline UNEP & United Nations Environment Programme \\
\hline UNEP-FI & United Nations Environment Programme - Finance Initiative \\
\hline UNESCO & United Nations Educational, Scientific and Cultural Organization \\
\hline UNICEF & World Business Council for Sustainable Development \\
\hline WBCSD & World Health Organization \\
\hline WHO & \\
\hline
\end{tabular}

